\title{
Liberating People, Critical Pedagogy on the Revolutionary Thought of Hassan Hanafi
}

\author{
M. Rodinal Khair Khasri \\ Universitas Gadjah Mada, Jogjakarta, Indonesia \\ m.rodinal.k@mail.ugm.ac.id
}

\begin{abstract}
The researcher observed the dimension of critical pedagogy in the context of Hassan Hanafi revolutionary thought. He was very good founding the fundamental thought in theology of liberation named Left Islam. This research used a literature study and historical-factual method to analyze the dimension of critical pedagogy on Hassan Hanafi revolutionary thought. The result of this research was new understanding about critical pedagogy dimension on Hassan Hanafi thought. First. Dehumanization in the context of education is inseparable from the influence of Western cultural imperialism. Second, The critical pedagogy found in Hassan Hanafi's thoughts is a pedagogy that aims to eliminate the destructive nature caused by the onedimensional view that results in educational disorientation from the true educational goal of liberating people.
\end{abstract}

Keywords: Critical pedagogy; dehumanization; existential consciousness; hassan Hanafi; revolution;

\begin{abstract}
Abstrak
Artikel ini mempresentasikan hasil penelitian terhadap pemikiran revolusioner Hassan Hanafi sehingga ditemukan dimensi pedagogi kritisnya. Hassan Hanafi merupakan sosok pemikir Islam yang sangat baik di dalam membangun pemikiran-pemikiran fundamental di dalam konteks teologi pembebasan, serta yang paling terkenal ia sebut dengan istilah "Kiri Islam". Penelitian ini termasuk dalam klasifikasi studi literatur dengan metode historis-faktual di dalam menganalisis dimensi pedagogi kritis di dalam pemikiran Hassan Hanafi. Hasil penelitian ini adalah pemahaman baru tentang dimensi pedagogi kritis di dalam pemikiran Hassan Hanafi. Pertama, dehumanisasi dalam konteks pendidikan adalah akibat dari pengaruh imperialisme budaya Barat. Kedua, pedagogi kritis Hasan Hanafi fokus pada upaya membangkitkan kesadaran eksistensial di tengah beragam permasalahan yang terjadi di masyarakat. Pedagogi kritis yang ditemukan di dalam pemikiran Hassan Hanafi merupakan pedagogi yang bertujuan untuk menghilangkan hal yang bersifat destruktif yang disebabkan oleh pandangan berdimensi-satu yang mengakibatkan disorientasi pendidikan dari tujuan pendidikan yang sesungguhnya yaitu memerdekakan manusia.
\end{abstract}

Kata kunci: Pedagogi kritis; dehumanisasi; kesadaran eksistensial; penindasan; revolusi. 


\section{2 | M. Rodinal Khair Khasri}

\section{Introduction}

Education must actually humanize humans, where the goal of education that must be held firmly. The nation's mental improvement is needed as a pillar of the nation in the process of sustainable development, namely the government, civil society or community, academics, entrepreneurs, and the media. This mental improvement is very possible to be realized through "character education" through formal and non-formal education. It takes critical reflection about the role of education in generating existential awareness of the people who will later become characters that are in accordance with the noble values held by the Indonesian people.

Therefore, critical pedagogy is an interesting thing to study and can also be a reference for the government in spawning educational policies in Indonesia. The emphasis on existential awareness of the real conditions that are afflicting the nation is very possible to be achieved through the application of critical pedagogies which are explored from the building of revolutionary and critical character thinking.

Regarding the condition of the Indonesian people, the majority of whom are devoted and very close to the appreciation of spiritual values, researcher is interested in choosing one of the contemporary Islamic philosophers who now serves as professor of philosophy at Cairo University in Egypt. His efforts in devoting his ideas of change to the awakening of existential awareness are very rich in driving forces that can be contextualized with the great idea of critical pedagogy which is the part of the philosophy of education, as well as a social movement that absorbs critical theoretical values in educating students to be more aware of any actual problem opressed their life. It is through strengthening existential awareness that educational output can be an agent of change in a society that is known for being religious.

\section{Theory Description}

In the study of education, there are two terms which often used in the discourse of education, namely pedagogy and paedagogiek. Pedagogy means education, while paeda means education. Pedagogic or educational sciences is the activity that 
focuse on encouraging, reflecting the symptoms of educating behavior. Pedagogia (Greece) means association with children. Meanwhile, those who often use the term paidagogos is a servant (bujang) in ancient Greece, whose job was to deliver and pick up children to and from school. Paidagogos comes from the word paedos (child) and agoge (I guide, leader). 1

Paidagogos's words, which at first meant servants, later turned into noble work. Because, understanding pai (from paidagogos) means a person whose job is to guide children in their growth towards being independent and responsible. In a simple and general sense, the meaning of education as a human effort to foster developing innate potentials, both physical and spiritual in accordance with the values that exist in society and culture. Efforts are made to instill these values and norms, and pass them on to the next generation to be developed in life and life that occur in an education. Because of that, however, a society's civilization and a process of education takes place as a human effort to preserve its life. In other words, education can be interpreted as the result of national civilization, developed on the basis of the nation's own life view (values and norms of society), which functions as the philosophy of education or as the ideal of its educational goals.2

The task of the philosophy of education is to deliver prospective teachers and education practitioners to deal with the big questions that underlie the meaning and purpose of education. For this reason, they must be familiar with the issues, such as the nature of reality, the meaning and source of knowledge, and the structure of values. 3

Educational philosophy brings students to situations when they intelligently assess alternative end goals, associate with desired goals, and select teaching methods according to purpose. Holistically, the task of educational philosophy helps educators think meaningfully about the totality of education and life

1 Muhammad Anwar, Filsafat Pendidikan (Jakarta: Prenadamedia Group, 2015).

2 Anwar.

3 Teguh Wangsa Gandhi, Filsafat Pendidikan (Yogyakarta: Ar-Ruzz Media Group, 2016). 


\section{4 | M. Rodinal Khair Khasri}

processes so that they are always in the right position and can develop programs that are consistent and comprehensive so that students are able to become qualified human beings. 4

In short, the philosophy of education intends to provide educators with the ability to understand the fundamental problems of education. Thus, enabling them to evaluate and continue to develop education becomes better. Ethically, the philosophy of education equips itself to carry out tracking about the purpose of life and education.5

The problems that are philosophically discussed by the philosophy of education, depart from the problems of education that are increasingly far from the ethical meaning of education. Education has even changed function into an industry that is fully alive and lived with and in economic laws. Therefore, it is often said how on campus and schools, a person will not meet with a teacher, instead only meet with a worker who is regulated and motivated by law and economic motives alone, so that it is far from the real meaning of the teacher. 6

\section{The Revolutionary Thoughts Of Hassan Hanafi}

In Hassan Hanafi there are two consciousness, namely cogito rationalism and existentialism ego which are represented in many years of his life: idealism-rationalism (1956-1960) and existentialism-realism (1961-1966). However, he maintained the optimism of idealism and ignored existentialism pessimism, preserved the role of reason (' $a q l$ ) in idealism and abandoned irrationality in existentialism, maintained the pragmatism argument in idealism and displaced uselessness in existentialism.7

The basis of Hassan Hanafi's epistemology is not solely based on Western consciousness and paradigm, but rooted in the consciousness and tradition of the Muslims. Furthermore, the basis of the epistemology is applied in reconstructing the new

4 Gandhi.

5 Gandhi.

6 Gandhi.

7 Hassan Hanafi, "Dari Akidah Ke Revolusi: Sikap Kita Terhadap Tradisi Lama,” trans. oleh A. U. Ismail (Jakarta Selatan: Paramadina, 2003). 
form of Kalam thoughts. In this case, the reconstruction takes a role of giving new meaning to the terms of the sentence and at once give a new name to these terms - that is new meaning of the Kalam. This reconstruction itself is a part of his mega project, namely al-yasar al-islami, revitalizing Islamic classical texts-including Kitabs of Salafussalih which discussed and explained Quran and Hadits-and also revitalizing Occidentalism. The meaning of "reconstructing the theology" is about to transform the meaning of term of theology in nature spiritual-religious into praxis hence will be able to lead ummah to understand their actual life and fight against every kind of oppression. 8

Liberation Theology also influenced Hassan Hanafi in inventing his thought about the left Islam, especially in founding the basic point of view in seeing opression among ummah. Amaladoss emphasizes that conditions are very ironic in Asia, even though the religiosity of people in Asia is very high but they still suffer, must be addressed by first understanding phenomena, especially the causes and structures that cause irony in Asia 9. Asia with its ironic, also related to the situation happened in Africa, and the rest of the region of Western occupation and this is the most stimulate thing which encouraged Hassan Hanafi to build his own thought about liberation theology.

According to him, reason and reality are both oriented to one action, namely praxis, which he found from one of the chapters in volume 1 of Logische Untersuchungen by Husserl. When he let go of the religious tradition from the source of revelation, the perfect unit of revelation, reason, and reality. This unity is the last part of his work entitled Manâhij at-Tafsîr (Les Méthodes d'Exégèse). This is what prompted Hassan Hanafi to translate works on "rational religion" (Kant) and "natural religion" (Lessing). At that time, Hassan Hanafi was

8 Hendri Nadiran, "Pemikiran Kalam Hassan Hanafi: Rekonstruksi Epistemologi Keilmuan Kalam dan Tantangan Modernitas," Intizar Vol.21 (2015): 247-59.

9 Michael Amaladoss, Life in Freedom: Liberation Theologies from Asia (New York: Orbis Books, 1997). 


\section{6 | M. Rodinal Khair Khasri}

closer to wahdah al-wujd (unity of existence) in the sense of subjective will as in the Ficthe view, not in the abstract sense in Schelling's view, which carried out the synchronization of Fichte's idealism and Hegel's idealism in forming philosophy of identity. He reads, lives, thinks and acts. Until now, for him, romanticism was the meeting point between idealism and existentialism, the meeting point between consciousness and life. Here, the Hassan Hanafi project that wants to create a new, universal-comprehensive methodology and Islamic theology continues but the approach has changed.10

In addition to a number of prominent European philosophers above, there are great thinkers in the Islamic world who have influenced Hassan Hanafi's critical thinking, especially in the leftist thoughts which are thick with revolutionary nuances, namely Al-Afghani and Ali Shari'ati. He adopted Al-Afghani's efforts to restore the glory of Islam into the "Islamic Left" concept. Al-Afghani well known for the rise of Islam by reopening the doors of Ijtihad, while Hassan Hanafi with his phenomenological approach tried to reinterpret the reality of the Islamic world, revitalizing the classical Islamic texts, which then led to the tauhid revolution so that the nuances of liberation which Islam was revealed could be realized.

Furthermore, we can see the revolutionary thoughts of Hassan Hanafi and the conditions for the movement against the political and cultural oppression directed at the Western world, strongly influenced by Ali Shari'ati's revolutionary thinking which was phenomenal in the realization of the Iranian Islamic revolution which was executed by Khomeini as a supreme "Imam" of the revolutionary movement. Many people knows Ali Syari'ati as an intellectual figure behind the grand revolution. Ali Syari'ati presented and introduced his teachings with what is termed liberation theology which combines reinterpretations of Islamic beliefs and modern socio-political thinking 11. Through the theology initiated by Shari'ati, it

10 Hassan Hanafi, "Studi Filsafat 1: Pembacaan Atas Tradisi Islam Kontemporer," trans. oleh Miftah Faqih (Yogyakarta: LkiS, 2015).

11 Edi Mas, "Revolusi Islam Iran dalam Pemikiran Ali Syari'ati" (Universitas Islam Negeri Sunan Kalijaga, 2016). 
strengthens the revolutionary nuances in Hassan Hanafi's thinking, one of which can be seen from his monumental summary work, "Islamic Left" (Al-Yasar al-Islami) and the great concept of Turats wa Tajdid (Tradition and Renewal)

\section{Critical Pedagogy}

In context of critical pedagogy, Paulo Freire is an important figure to study. In this study, the figure of Freire is one of the secondary references in mapping the dimensions of critical pedagogy that will be investigated in Hassan Hanafi's thought. Pedagogy has been growing in the Western world with the mainstream of modernism thinking, which is characterized by worship of science and technology and welcomed by people who generally adopt a free market economy. The thinking of Freire is often associated with "critical ideology" containing social change, but also growing in the Western world. Because of that, it is alleged that Freire's pedagogy is more complete and comprehensive. Freire's pedagogy is not merely a didactic or merely oriented teaching of knowledge and skills. 12 Stevens explained that the literacy program (literacy eradication) does not merely aim at reading letters, but also consciousness, namely learning to perceive contradictions or social, political, and economic disparities - developing a critical awareness - so that individuals can take action to counter the oppressive elements of reality 13 .

As a subject, relations between humans become equal, namely the relation of subjects to other subjects 14 . Freire explains that his education requires individuals to be "A deepened consciousness of their situation leading people to apprehend that situation as historical reality susceptible of transformation" 15 .

12 Dharma Kesuma, "Struktur Fundamental Pedagogi Paulo Freire dan Relevansinya untuk Pendidikan Indonesia" (Universitas Pendidikan Indonesia, 2013).

13 Kesuma.

14 Kesuma.

15 Kesuma. 


\section{8 | M. Rodinal Khair Khasri}

Critical pedagogy is becoming increasingly important, when people live in a society full of oppression and injustice. In such a society, many people do not have the opportunity to determine their own lives, and participate in managing their communities. In short, he cannot fully express his humanity. In this kind of society, according to Giroux, critical pedagogy can be a tool to build awareness and encourage broad social change. It is a form of theoretical and political action to understand and change society. Critical pedagogy is more than just a method usually used in research and education. In this kind of educational paradigm, students are seen as obedient robots who are ready to be ordered to pursue something. Questions of social justice, values, ethics and power relations in society are kept away from the teaching model and education curriculum. 16

Critical pedagogy also has another side, namely the side of hope and possibility. The basis of this hope and possibility is democracy itself which is based on equality and freedom. These two things also, namely freedom and equality, which are often sacrificed in the application of traditional pedagogy. Educational pedagogy encourages children to think critically with freedom and responsibility. Pedagogy should not make children merely passive recipients of teaching materials that are based on blind obedience. With critical thinking skills, which are based on criticism and hope, the school will be a place to train sensitivity to suffering and be solidarity with others. Pedagogy has also changed to encourage students to engage in social change towards freedom, democracy and equality. 17

Critical pedagogy has a basic view that education is politics. In a sense, all educational activities are basically political and have political consequences and quality. In the context of education policy for instance, it always has implications for accommodating one's interests groups and marginalization of other group interests. In the context of pedagogy, the way the

16 Reza Antonius Alexander Wattimena, "Pemikiran Henry Giroux Tentang Pendidikan Dan Relevansinya Untuk Indonesia," Jurnal Filsafat 28, no. 2 (2018): 180-99.

17 Wattimena. 
teacher / teaches and the choice of knowledge being taught, everything has political implications. 18

\section{Critical Pedagogy on the Revolutionary Thought of Hassan Hanafi}

Hassan Hanafi's extensive critical thinking, drawn in his thoughts, namely two concepts: Left Islam (Al-Yasar al-Islami) and the big concept of Turats wa Tajdid (Tradition and Renewal).

In the context of critical pedagogy, awareness is the thing that is the fulcrum in creating a democratic and equal education atmosphere. Not only focus on students, but also still have to concern about the education system which is actually a source of problems which then determine the success or failure of an educational process.

According to his Left Islam, there are demands and guidance about Islamic education - it was the representation of critical pedagogy - that both the thoughts and deeds of Islamic education, towards awareness (rationalistic) and experience (empiricist) education in which there is inherently immortality which resulted in the education's completeness being inherited as the direction of shifting the transition motion from potential to actual which involves existential work. So that education is also closely related to innovation and progressiveness as power battering ram which begins freedom and independence in the direction of enlightenment - the same as the conservative side which is not independent and cannot be separated from the existential work to arrive at Axiological goal. That was usually universal being nature (conservative) as the direction of shifting the movement of direction (intentionality) - hence it will be dynamics (innovative and progressive) meaningful, useful, and also support the realization of prosperity constructive, and decrease everything that caused the destruction of humanities.19

18 Tabrani Z. A., "Isu-isu Kritis dalam Pendidikan Islam Menurut Perspektif Pedagogi Kritis," Islam Futura 13, no. 2 (2014): 250-70.

19 Achmad Reyadi, "KONSTRUKSI PENDIDIKAN KIRI ISLAM (Membumikan Pemikiran Hassan Hanafi)," Tadrîs Vol.8, no. 1 June 2013 (2013): 70-90. 


\section{0 | M. Rodinal Khair Khasri}

Hassan Hanafi's thought said that critical pedagogy is a branch of the philosophy of education that is thick with nuances of liberation. One of the points in Hassan Hanafi's thinking emphasized here is the need to revitalize classical Islamic texts as a representation of communal historical consciousness, which also has implications for individual consciousness in interpreting the reality for liberating their life from any kind of oppression. From that basic idea, we can find the critical pedagogy dimension in Hassan Hanafi's revolutionary thoughts. Previously both Hassan Hanafi and his readers had never written explicitly about pedagogy, because according to the understanding of researchers, the fundamental idea of Hassan Hanafi who was very critical and revolutionary could be contextualized into all lines of human life in the frame of resistance to the practice of dehumanization within any kind of oppression.

First, Hassan Hanafi emphasize on the need to revitalize classical Islamic texts that could be juxtaposed with the values of Tawheed - as the core of the teachings of Islam. Understanding of Tawheed really must be understood correctly and fundamentally and not only be understood as symbolic things in the legal-formal corridor. Understanding is needed which involves critical thinking activities so as to generate existential awareness that is also relevant to strengthen the value of Tawheed itself. It is indeed difficult to present empirical evidence regarding the experience of divinity in the building of Tawheed. This has made Hassan Hanafi strongly reject Western cultural imperialism, which in fact has become the culprit for the emergence of a one-dimensional-borrowing the terms of Herbert Marcuse-, which focuses on only one life goal directed by capitalist ideology, for instance the view of materialismpragmatism.

Furthermore, that is interpreting reality through hermeneutics over the history of the Ummah. The reality in question is the real condition that is being faced by the people, because education is not only focus on the process of transferring information, but also must touch the realm of social praxis that can answer the challenges of increasingly complex social problems. Social problems are exacerbated by the 
deterioration of existential consciousness, which plunges education into black holes that caused distortion in understanding reality. Education is only directed to create human beings whose economic calculations are arguably superior, because it is likened to the point of view of a mechanical machine that can boost capital income. This is what Hassan Hanafi calls the impact of Western cultural imperialism which is full of lustful desire for modernism which then uses the platform of liberal-capitalist ideology to strengthen its grip on non-Westerners or destinations to exploit its resources, both human and natural resources. Existential awareness cannot be achieved if the understanding of reality is still blurred.

Interpreting is making multiple movements, from text to reality and vice versa. The first is realized through the amphibian principle of language-similar to the binary opposition. Second, realized through feeling (Zeitgeist). Language without reality is empty, so reality without language is blind. "Die Sprache ist dass Haus des Seins". Amphibological principles give the interpreter the freedom to read himself and his community in the text. Text has a double side according to multiple social structures in every society. The role of the interpreter is to produce text on one side. Many of the amphibian principles include justification and calculation, exoteric and esoteric, univocal and equivocal, clarity and obscurity, special and general.20

Through the interpretation of the text towards the reality of the people or society, the output of education that is in accordance with the objectives of the critical pedagogy can be fully realized. Collective and individual awareness as a logical implication of interpretation is guidance in applying the principles of critical pedagogy in the context of education in the country. Thus the success of students is not only assessed numerically, but must exceed the numbers.

Appreciation for students does not only stop at moral appreciation in schools, but must be able to contribute to

20 Hassan Hanafi, "Dari Akidah ke Revolusi: Sikap Kita Terhadap Tradisi Lama," trans. oleh Asep Usman Ismail (Jakarta Selatan: Paramadina, 2003). 


\section{2 | M. Rodinal Khair Khasri}

society. If the current mainstream education, especially at the level of senior secondary education to tertiary education, is always focused on matters of economic value, then critical pedagogy focuses more on how education can create conditions for an egalitarian society. The true egalitarian society is a condition for the realization of a prosperous society. Hassan Hanafi saw that inequality was caused by a high sense of ownership of the material. If the religious community truly maximizes the appreciation of spirituality or faith as the direction and guidance of praxis, then excessive desire for matter can be reduced. This is actually in line with the values of liberation in the context of Islam.

Hassan Hanafi emphasized that ownership is only a social function21. Thus, God gives humans trust based on their natural function only. Humans in relation to something have the right to use, not to abuse, and to plant, not to act as a capitalist, and to develop, not to monopolize22. Similarly, education, all forms of privatization of education as part of the capitalization of education are potential to reduce human values, including freedom and human rights to be equal socially, politically, lawfully and economically. In fact, the truly egalitarian society has been affirmed by God through His words in the Quran.

If we understood critical pedagogy as a political action to achieve an egalitarian society order through democratic and equal education, then seeking public interest over group or personal interests can be done by optimizing the potential of students by not restraining them with a rigid and undemocratic curriculum. In addition to the curriculum, education politics affected by central policy holders must be fair in spawning policies regarding education. So, the proper education should be accessible to anyone, from all elements of society. This is the purpose of the education. Not only as an ideal value, but through critical pedagogy extracted from Hassan Hanafi's thought, the change against dehumanize oppressions becomes more effective

21 Hassan Hanafi, "Bongkar Tafsir: Liberalisasi, Revolusi, dan Hermeneutik," trans. oleh Jajat Hidayatul Firadaus dan Neila Meuthia Diena Rochman (Yogyakarta: Prismasophie Pustaka Utama, 2003).

22 Hanafi. 
because the movement starts from strengthening existential awareness and moving from the inside out. The point is that mental revolution will be maximal if it rests on strong existential awareness.

\section{Conclusion}

The critical pedagogy tradition stated that a voice depicts the historical make-up and social experiences of individuals who have been at once alienated, oppressed, and subordinated. A language of possibility allows students and teachers to share and understand their respective voices in light of structural configurations, such as race, class, gender, and age. 23

According to Hassan Hanafi, dehumanization in the context of education is inseparable from the influence of Western cultural imperialism. Through a series of critical steps, it can be a consideration in developing curriculum and government policies on education, so that elements outside the educational context that become parasitic can be tamed so that education can truly become a political action in addressing problems socialcommunity.

Critical pedagogy explored from Hassan Hanafi's thinking is a critical pedagogy that seeks to stem the destructive things which caused by a one-dimensional view, which was reducing the real purpose of education. Furthermore, Hassan Hanafi's efforts in arising existential awareness cannot be separated from the religious foothold, which is reinterpreted, based on philosophical interpretations so that the normative aspects of religion should not stop at mere theoretical normative levels, but must be able to speak for practical rights.

\section{References}

Amaladoss, Michael. Life in Freedom: Liberation Theologies from Asia. New York: Orbis Books, 1997.

Anwar, Muhammad. Filsafat Pendidikan. Jakarta: Prenadamedia Group, 2015.

Bakker, Anton, dan Charris Zubair. "Metodologi Penelitian Filsafat.” Yogyakarta: Penerbit Kanisius, 1990.

23 Barry Kanpol, "Critical Pedagogy and Liberation Theology: Borders For a Transformative Agenda" (Penn State-Harrisburg, 1996). 


\section{4 | M. Rodinal Khair Khasri}

Darmaningtyas, Edi Subkhan, dan Fahmi Panimbang. "Melawan Liberalisme Pendidikan." Malang: Madani, 2014.

Gandhi, Teguh Wangsa. Filsafat Pendidikan. Yogyakarta: ArRuzz Media Group, 2016.

Hanafi, Hassan. "Bongkar Tafsir: Liberalisasi, Revolusi, dan Hermeneutik." Diterjemahkan oleh Jajat Hidayatul Firadaus dan Neila Meuthia Diena Rochman. Yogyakarta: Prismasophie Pustaka Utama, 2003.

"Dari Akidah Ke Revolusi: Sikap Kita Terhadap Tradisi Lama.” Diterjemahkan oleh A. U. Ismail. Jakarta Selatan: Paramadina, 2003.

. "Dari Akidah ke Revolusi: Sikap Kita Terhadap Tradisi Lama." Diterjemahkan oleh Asep Usman Ismail. Jakarta Selatan: Paramadina, 2003.

—. "Studi Filsafat 1: Pembacaan Atas Tradisi Islam Kontemporer." Diterjemahkan oleh Miftah Faqih. Yogyakarta: LkiS, 2015.

Kanpol, Barry. "Critical Pedagogy and Liberation Theology: Borders For a Transformative Agenda." Penn StateHarrisburg, 1996.

Kesuma, Dharma. "Struktur Fundamental Pedagogi Paulo Freire dan Relevansinya untuk Pendidikan Indonesia." Universitas Pendidikan Indonesia, 2013.

Mas, Edi. "Revolusi Islam Iran dalam Pemikiran Ali Syari'ati." Universitas Islam Negeri Sunan Kalijaga, 2016.

Nadiran, Hendri. "Pemikiran Kalam Hassan Hanafi: Rekonstruksi Epistemologi Keilmuan Kalam dan Tantangan Modernitas." Intizar Vol.21 (2015): 247-59.

Reyadi, Achmad. "KONSTRUKSI PENDIDIKAN KIRI ISLAM (Membumikan Pemikiran Hassan Hanafi)." Tadrîs Vol.8, no. 1 June 2013 (2013): 70-90.

Wattimena, Reza Antonius Alexander. "Pemikiran Henry Giroux Tentang Pendidikan Dan Relevansinya Untuk Indonesia." Jurnal Filsafat 28, no. 2 (2018): 180-99.

Z. A., Tabrani. "Isu-isu Kritis dalam Pendidikan Islam Menurut Perspektif Pedagogi Kritis." Islam Futura 13, no. 2 (2014): 250-70. 